\section{Temperature and Cultivar Effects on Anthocyanin and Chlorophyll b Concentrations in Three Related Lollo Rosso Lettuce Cultivars}

\author{
Aparna Gazula, ${ }^{1}$ Matthew D. Kleinhenz, ${ }^{2}$ John G. Streeter, ${ }^{3}$ and \\ A. Raymond Miller ${ }^{3}$ \\ The Ohio State University, Ohio Agricultural Research and Development \\ Center, Department of Horticulture and Crop Science, 1680 Madison Avenue, \\ Wooster, OH 44691-4096 \\ Additional index words. antioxidant, leaf color, crop quality, stress, 'Lotto', 'Valeria', \\ 'Impuls', growth chamber, controlled environment
}

\begin{abstract}
Pigment concentrations in leaf tissue affect the visual and nutritional value-based indices of lettuce crop quality. To better discern the independent and interactive effects of temperature and cultivar on anthocyanin and chlorophyll b concentrations, three closely related Lolla Rosso lettuce cultivars ('Lotto', 'Valeria', and 'Impuls'), varying primarily in the number of genes controlling anthocyanin concentrations, were subjected to different air temperatures in controlled environments. Fifteen-day-old seedlings previously grown at $20{ }^{\circ} \mathrm{C}$ day/night $(\mathrm{D} / \mathrm{N})$ were transplanted into growth chambers maintained at $20^{\circ} \mathrm{C}$ $(\mathrm{D} / \mathrm{N}), 30 / 20{ }^{\circ} \mathrm{C} \mathrm{D} / \mathrm{N}$ and $30{ }^{\circ} \mathrm{C} \mathrm{D} / \mathrm{N}$ air temperatures. Twenty days later, leaf tissue was sampled for measures of pigment concentrations, calculated based on spectrophotometric absorbance readings taken at $530 \mathrm{~nm}$ (anthocyanin) and $660 \mathrm{~nm}$ (chlorophyll b) respectively. Although significant, the temperature $\times$ cultivar interaction resulted from differences in the magnitude (not direction) of the change in pigment concentrations among cultivars with changes in temperature. Regardless of cultivar, anthocyanin and chlorophyll b concentrations were highest, moderate and lowest after growth at $20{ }^{\circ} \mathrm{C} \mathrm{D} / \mathrm{N}, 30 / 20{ }^{\circ} \mathrm{C}$ $\mathrm{D} / \mathrm{N}$ and $30^{\circ} \mathrm{C} \mathrm{D/N}$ respectively. Likewise, irrespective of temperature, anthocyanin and chlorophyll b concentrations followed the pattern 'Impuls' (three genes) > 'Valeria' (two genes) $>$ 'Lotto' (one gene). These data provide additional strong evidence that lettuce leaf pigment concentrations and growing temperatures are negatively related. The data also suggest that low temperatures during the dark phase may mitigate high temperaturedriven reductions in lettuce leaf pigment levels.
\end{abstract}

Coloration (intensity, distribution) and nutritional value are important quality parameters in lettuce (Kader et al., 1973; Ryder, 1999a; Simonne et al., 2002) and are based, in part, on anthocyanin and chlorophyll levels.

Biotic (genetics, growth stage, disease) and abiotic (temperature, light, water potential, nutrient availability) factors which affect lettuce growth are also reported to influence anthocyanin and chlorophyll concentrations in various tissues of other horticultural crops

\footnotetext{
Received for publication 15 Mar. 2005. Accepted for publication 17 May 2005. HCS 05-19. Salaries and research support provided in part by State and Federal funds appropriated to the Ohio Agricultural Research and Development Center (OARDC), The Ohio State University. Research supported by the OARDC Research Enhancement Competitive Grants Program (Seed Grant Competition) and the Dept. of Horticulture and Crop Science Vegetable Endowment, per The OSU Vegetable Team. We thank A. van der Arend, Nunhems Seed Co., Bert Bishop, Lee Duncan and Marcia Feller for seed and technical assistance. Use of trade names does not imply endorsement of the products named nor criticism of similar ones not named. Work completed in partial fulfillment of the M.S. degree of Aparna Gazula. ${ }^{1}$ Graduate research associate.

${ }^{2}$ Associate professor and corresponding author; kleinhenz.1@osu.edu.

${ }^{3}$ Professor.
}

(Dela et al., 2003; Maza and Miniati, 1993; Oren-Shamir and Levi-Nissim, 1999; Reay 1999; Shaked-Sachray et al, 2002; Shvarts et al., 1997a, 1997b; Wang and Zheng, 2001). Genotype, temperature and light are reported to act alone and together in shifting lettuce pigment levels (Crozier et al., 1997; Ferreres et al., 1997; Kleinhenz et al, 2003; Robinson et al., 1986; Ryder 1999b; Voipio and Autio, 1995). Still, these effects are incompletely characterized.

In lettuce, a complementary gene pair $(\mathrm{CcGg})$ controls the presence or absence of anthocyanins, predominately cyanidin 3-malonylglucoside (Yamaguchi et al., 1996), while a multiple allelic system governs the pattern of red coloration (Robinson et al., 1986; Ryder, 1999b; Thompson, 1938). For this study, we employed three closely related red-leaved, Lollo Rosso cultivars ['Lotto', 'Valeria', and 'Impuls' (Nunhems Seed, Haelen, Netherlands)] differing mainly in the number of genes controlling anthocyanin levels. 'Lotto' ( 1 gene for color intensity) is the best type selection of the cultivars 'Lollo Bionda' and 'Lollo Rosso', 'Valeria' (2 genes) is a morered mutant of 'Lotto' and 'Impuls'(3 genes) is a more-red mutant of 'Valeria'(A. vad der Arend, personal communication).

Studies on the environmental regulation of anthocyanin and chlorophyll levels in other horticultural crops are key but insufficient to explain similar phenomena in lettuce. Diversity in crop and tissue physiology and pigment forms and distribution leave open the possibility that pigment regulation in lettuce may differ from that in other crops. Regardless, the prominence of lettuce in vegetable industries and human diets worldwide calls for studies which help to enhance its quality (appearance and nutritional value), including through genetic and horticultural manipulation. Temperature may modulate anthocyanin and chlorophyll levels in lettuce (Kleinhenz et al., 2003; Voipio and Autio, 1995), but additional information is needed to confirm and characterize this regulation. Therefore, we set out to further clarify the effect of temperature on anthocyanin and chlorophyll b levels in immature lettuce, using controlled environments and a set of closely related cultivars.

\section{Materials and Methods}

Plant material and growth conditions. Individual seeds of 'Lotto', 'Valeria', and 'Impuls' were sown in polypropylene, D16 Deepot cells [ $5 \mathrm{~cm}$ in diameter, $18 \mathrm{~cm}$ in height, $262 \mathrm{~mL}$ (Stuewe and Sons, Inc., Corvallis, Ore.)] filled with $170 \mathrm{~mL}$ of Metro-Mix 360 (Scotts-Sierra Horticultural Products Co., Marysville, Ohio) growing medium. Four cells, each containing a single plant of each cultivar were then placed in random locations within D16 Deepot trays [61 cm in length, $30 \mathrm{~cm}$ in width, $172 \mathrm{~cm}$ in height (Stuewe and Sons)], each tray holding a total of twelve Deepot cells. Four trays were then placed in random locations within each of three different growth chambers (CONVIRON 4030 model \# E15, Controlled Environments Incorporation, Manitoba, Canada). Thus, each growth chamber contained 16 plants per cultivar. Growth chambers were maintained at a constant air temperature of $20^{\circ} \mathrm{C}$ for 15 d. Thereafter, one chamber was maintained at $20^{\circ} \mathrm{C}$ day/night $(\mathrm{D} / \mathrm{N})$, the second at $30^{\circ} \mathrm{C}$ $\mathrm{D} / \mathrm{N}$, and the third at $30 / 20^{\circ} \mathrm{C} \mathrm{D} / \mathrm{N}$. All plants received $600 \mu \mathrm{mol} \cdot \mathrm{m}^{-2} \cdot \mathrm{s}^{-1}$ of light energy at canopy height from sixteen 1500 milliamp fluorescent light tubes (General Electric Lighting, Cleveland, Ohio) and twelve 60-W incandescent bulbs (General Electric Lighting, Cleveland, Ohio) for a 12-h light period each day, regardless of temperature regimen. Each plant was irrigated by hand once daily with 200 $\mathrm{mL}$ of tap water, with about $100 \mathrm{~mL}$ draining soon after irrigation. Plants were also fertilized weekly with a $200 \mathrm{mg} \cdot \mathrm{L}^{-1}(\mathrm{ppm})$ solution made with Peter's 20-20-20 Professional Water Soluble Fertilizer [20N-8.7P-16.6K (ScottsSierra Horticultural Products Co., Marysville, Ohio)]. Using this method, each plant received about $2.6 \mathrm{mg} \mathrm{N}, 1.2 \mathrm{mg}$ of $\mathrm{P}$, and $2.2 \mathrm{mg}$ of $\mathrm{K}$ each week.

A completely randomized design with four replications per temperature-cultivar combination was used. The entire experiment was conducted twice.

Anthocyanin and chlorophyll b extraction and quantification. Samples were collected from the most fully expanded leaf (third leaf 
from the outer whorl) on three plants per cultivar per replicate (tray) in each growth chamber $20 \mathrm{~d}$ after the initiation of temperature treatments, as previously described (Kleinhenz et al., 2003). Samples remained in storage at $-20{ }^{\circ} \mathrm{C}$ until pigment extraction. Total leaf fresh and dry weight measurements were also taken on all sampled plants.

Pigment extraction and quantification was completed as described previously (Kleinhenz et al., 2003) with four minor exceptions. First, absorbance readings corresponding to anthocyanin pigments were measured at $530 \mathrm{~nm}$. This wavelength led to maximum absorption in wavelength scans taken with a HP 8452 Diode array spectrophotometer(Hewlett-Packard Co., Palo Alto, Calif.) and has also been used previously (Pietrini et al., 2002; Reay, 1999). Second, absorbance readings for anthocyanin and chlorophyll $\mathrm{b}$ pigments were measured with a spectrophotometer(DU 640; Beckman Coulter, Inc., Fullerton, Calif.). Third, standard curves were developed using HPLC grade cyanidin 3-glucoside (Chromadex, Santa Ana, Calif.) and laboratory grade chlorophyll b (Sigma-Aldrich, St. Louis, Mo.). Finally, here we elected to document temperature effects on chl b only. While chlorophyll a degraded more rapidly than chlorophyll b in Brassica and Ipomoea sp. leaf disks subjected to gradual- and rapid-boiling treatments in the lab (Chao and Yang 1996), mean levels of chlorophyll a and chlorophyll $b$ in intact lettuce leaves were not differentially affected by greenhouse light and temperature treatments (Kleinhenz et al., 2003).

Statistical analysis. Preliminary analysis indicated that treatment effects did not differ between replicates in time (i.e., runs of the study). Therefore, data from both runs were pooled and subjected to analysis of variance (ANOVA) using Statistical Analysis System version 8e for Windows (SAS Institute, Cary, N.C.), with effects considered significant when $p \leq 0.01$. Treatment effects were analyzed by $t$ tests (LSD) with $\alpha=0.01$.

\section{Results and Discussion}

Tissue percent moisture values were similar among temperature-cultivar treatments, with mean values of $94 \%$ to $96 \%$ (data not shown). Therefore, treatment effects on pigment concentrations expressed on a fresh weight and dry weight basis were similar. Temperature and cultivar significantly affected anthocyanin and chlorophyll b concentrations (Table 1). Although significant, the interaction was due to a difference in the magnitude of the change in response, not its direction (Fig. 1). Irrespective of temperature, anthocyanin and chlorophyll b concentrations were lowest in 'Lotto', intermediate in 'Valeria', and highest in 'Impuls' (Fig. 1). Likewise, regardless of cultivar, anthocyanin and chlorophyll b concentrations were lowest, intermediate and highest at $30 / 30{ }^{\circ} \mathrm{C} \mathrm{D} / \mathrm{N}, 30 / 20{ }^{\circ} \mathrm{C} \mathrm{D} / \mathrm{N}$ and $20 / 20{ }^{\circ} \mathrm{C}$ $\mathrm{D} / \mathrm{N}$, respectively (Fig. 1). These results are additional, strong evidence that low temperatures may increase anthocyanin and chlorophyll b concentrations in red Lollo Rosso lettuce, as reported earlier in other lettuces (Kleinhenz et al., 2003) and horticultural crops (Leng and Qi, 2003; Shvarts et al., 1997a, 1997b). In contrast, anthocyanin concentrations increased

in strawberry fruit and Pinus sp. needles following high temperature exposure (Sallas et al., 2003; Wang and Zheng, 2001).

Table 1. Analysis of variance for the impact of cultivar and temperature on anthocyanin and chlorophyll b concentrations in leaves of lettuce grown in environmentally controlled growth chambers at The Ohio State University, Columbus, Ohio. The study was conducted twice.

\begin{tabular}{lccc}
\hline Source & df & $\begin{array}{c}\text { Anthocyanin } \\
\text { concn }\end{array}$ & $\begin{array}{c}\text { Chlorophyll b } \\
\text { concn }\end{array}$ \\
\hline Temperature $(\mathrm{T})^{\mathrm{z}}$ & d & $* *$ & $* *$ \\
Cultivar $(\mathrm{C})^{\mathrm{y}}$ & 2 & $* *$ & $* *$ \\
$\mathrm{~T} \times \mathrm{C}$ & 2 & $* *$ & $* *$ \\
\hline
\end{tabular}

${ }^{2}$ Temperatures are $20 / 20{ }^{\circ} \mathrm{C}$ day/night $(\mathrm{D} / \mathrm{N}), 30 / 20{ }^{\circ} \mathrm{C} \mathrm{D} / \mathrm{N}$, and $30 / 30{ }^{\circ} \mathrm{C} \mathrm{D} / \mathrm{N}$.

${ }^{y}$ Cultivars are 'Lotto', 'Valeria', and 'Impuls'.

${ }^{* *}$ Significant at $p \leq 0.01$ for each source.
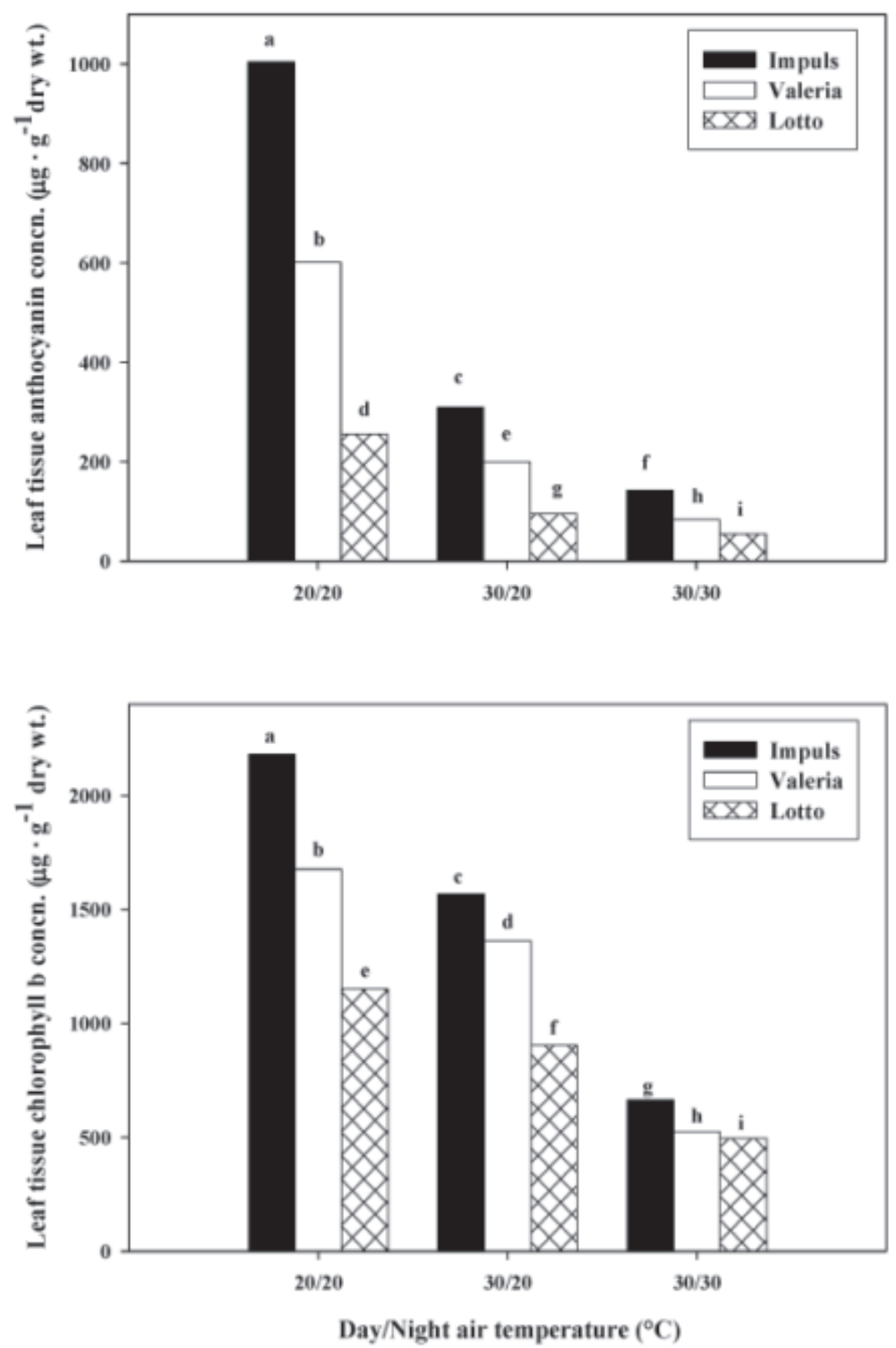

Fig. 1. Anthocyanin (top) and chlorophyll b (bottom) concentrations in leaf tissue of three Lollo Rosso lettuce cultivars ('Lotto', 'Valeria', 'Impuls') grown at $20 / 20{ }^{\circ} \mathrm{C}, 30 / 20{ }^{\circ} \mathrm{C}$, and $30 / 30{ }^{\circ} \mathrm{C}$ day/night $(\mathrm{D} / \mathrm{N})$ in controlled environment growth chambers. Bars within panels topped by the same letter are not significantly different according to Fisher's least significant difference test $(\alpha=0.01)$. Values shown are the means of 24 observations per cultivar per temperature treatment. 
Fluctuating day/night air temperatures of $30 / 20{ }^{\circ} \mathrm{C} \mathrm{D} / \mathrm{N}$ resulted in higher anthocyanin and chlorophyll $\mathrm{b}$ concentrations than $\mathrm{a}$ constant $30 / 30{ }^{\circ} \mathrm{C} \mathrm{D} / \mathrm{N}$ temperature regimen (Fig. 1). This result is cause to speculate that the detrimental effects of a daytime high temperature treatment $\left(30^{\circ} \mathrm{C}\right)$ on anthocyanin and chlorophyll $\mathrm{b}$ levels can be mitigated with a nighttime low temperature treatment $\left(20^{\circ} \mathrm{C}\right)$, especially in lettuce cultivars predisposed to contain relatively high levels of anthocyanins (e.g., 'Valeria', 'Impuls'). Possible explanations for temperature effects found here include enhanced production and/or retarded degradation of pigment levels. Low temperatures are thought to increase the transcript levels of genes, whose products phenylalanine ammonia lyase and chalcone isomerase, are enzymes involved in anthocyanin biosynthesis (Dela etal., 2003). This phenomenon may help to explain the higher levels of anthocyanin in the fluctuating temperature treatment. Furthermore, temperatures affect pigment stability, with evidence for increased pigment degradation at higher temperatures (Chao and Yang, 1996; Shaked-Sachray et al, 2002).

Understanding temperature effects on pigment concentrations in lettuce has practical and scientific value, including in cultivar development and selection and croppingstorage-distribution systems design and management. Using a set of genetically similar cultivars grown under controlled environment conditions, we provide additional, strong evidence that anthocyanin and chlorophyll $b$ concentrations in lettuce may be reduced at temperatures above those considered optimal for lettuce growth.

\section{Literature Cited}

Chao, P.Y. and C.M. Yang. 1996. Effect of heating pattern on pigment degradation of green veg- etable leaf. Taiwania 41:339-345.

Crozier, A., M.E.J. Lean, M.S. McDonald, and C. Black. 1997. Quantitative analysis of the flavonoid content of commercial tomatoes, onions, lettuce, and celery. J. Agr. Food Chem. 45:590-595.

Dela, D., E. Or, R. Ovadia,A.Nissim-Levi, D. Weiss, and M. Oren-Shamir. 2003. Changes in anthocyanin concentration and composition in 'Jaguar' rose flowers due to transient high-temperature conditions. Plant Sci. 164:333-340.

Ferreres, F., M.I. Gil, M. Castañer, and F.A. TomásBarberán. 1997. Phenolic metabolites in redpigmented lettuce (Lactuca sativa). Changes with minimal processing and cold storage. J. Agr. Food Chem. 45:4249-4254.

Kader, A.A., W.J. Lipton, and L.L. Morris. 1973. Systems for scoring quality of harvested lettuce. HortScience 8:408-409.

Kleinhenz, M.D., D.G. French, A. Gazula, and J.C. Scheerens. 2003. Variety, shading and growth stage effect on pigment concentrations in lettuce grown under contrasting temperature regimens. HortTechnology 13:677-683.

Leng, P. and J.X. Qi. 2003. Effect of anthocyanin on David peach (Prunus davidiana Franch) under low temperature stress. Scientia Hort. 97:27-39.

Mazza, G. and E. Miniati. 1993. Anthocyanins in fruits, vegetables, and grains. CRC Press, Boca Raton, Fla.

Oren-Shamir, M. and A. Levi-Nissim. 1999. Temperature and gibberellin effects on growth and anthocyanin pigmentation in Photinia leaves. J. Hort. Sci. Biotechnol. 74:355-360.

Pietrini, F., M.A. Iannelli, and A. Massacci. 2002. Anthocyanin accumulation in the illuminated surface of maize leaves enhances protection from photo-inhibitory risks at low temperature, without further limitation to photosynthesis. Plant Cell Environ. 25:1251-1259.

Reay, P.F. 1999. The role of low temperatures in the development of the red blush on apple fruit ('Granny Smith'). Scientia Hort. 79:113-119.

Robinson, R.W., J.D. McCreight, and E.J. Ryder. 1986. The genes of lettuce and closely related species. Plant Breed. Rev. 1:267-293.
Ryder, E.J., 1999a. Marketing economics and food safety, p. 164-171. In: E.J. Ryder (ed.). Lettuce, endive and chicory. CAB Intl. Publ., New York.

Ryder, E.J., 1999b. Genetics and breeding, p. 28-53. In: E.J. Ryder (ed.). Lettuce, endive and chicory. CAB Intl. Publ., New York.

Sallas, L., E. Luomala, J. Utriainen, P. Kainulainen, and J.K. Holopainen. 2003. Contrasting effects of elevated carbon dioxide concentration and temperature on Rubisco activity, chlorophyll fluorescence, needle ultrastructure and secondary metabolites in conifer seedlings. Tree Physiol. 23:97-108.

Shaked-Sachray, L., D. Weiss, M. Reuveni, A. Nissim-Levi, and M. Oren-Shamir. 2002. Increased anthocyanin accumulation in aster flowers at elevated temperatures due to magnesium treatment. Physiol. Plant. 114:559-565.

Shvarts, M., D. Weiss, and A. Borochov. 1997a. Temperature effects on growth, pigmentation and post harvest longevity of petunia flowers. Scientia Hort. 69:217-227.

Shvarts, M., A. Borochov, and D. Weiss. 1997b. Low temperature enhances petunia flower pigmentation and induces chalcone synthase gene expression. Physiol. Plant. 99:67-72.

Simonne, A., E. Simonne, R. Eitenmiller, and C.H. Coker. 2002. Bitterness and composition of lettuce varieties grown in the Southeastern United States. HortTechnology 12:721-726.

Thompson, R.C. 1938. Genetic relations of some color factors in lettuce. Techn. Bul. 620, USDA, Washington, D.C.

Voipio, I. and J.Autio. 1995. Responses of red-leaved lettuce to light intensity, UV-Aradiation and root zone temperature. Acta Hort. 399:183-187.

Wang, S.Y. and W. Zheng. 2001. Effect of plant growth temperature on antioxidant capacity in strawberry. J. Agric. Food Chem. 49:49774982.

Yamaguchi, M., S. Kawanobu, T. Maki, and I. Ino. 1996. Cyanidin 3-malonylglucoside and malonyl-coenzyme A: Anthocyanidin malonyltransferase in Lactuca sativa leaves. Phytochemistry 42:661-663. 